\title{
A COLLEGE PROGRAM FOR RURAL SOCIOLOGY
}

\author{
ERNEST R. GROVES \\ College of Liberal Arts, Boston University
}

The departments of sociology in the American colleges can no longer be charged with the neglect of the rural community. No division of the science of sociology has made more rapid progress during the last ten years than has rural sociology. This progress has been mostly due to the emphasis that rural sociology has received in the program of the sociological departments of the colleges. Courses have been established in the majority of the colleges where sociology is taught, research has been undertaken, especially in the form of survey studies, and recognition for the rural social interests has been obtained at national conferences. The pioneer days of rural sociology are coming to an end, and from now on the importance of this division of social science will be taken for granted. The need of pleading the importance of rural social interests has passed. The teacher of rural sociology must now increasingly busy himself with the routine of teaching and with the problem of increasing the scientific value of his subject-matter.

Teachers of rural sociology frankly confess their present difficulties in teaching their subject. There can be no reasonable question in regard to the importance of the social life of the rural community, but it is open to discussion whether we have as yet enough substantial knowledge regarding this social life to afford a comfortable teaching equipment for the instructor. To state this does not mean to discount in any degree the value of texts recently published. The task of the teacher of rural sociology has been lightened by these texts, but the books themselves bear the marks of the pioneering days of the study of rural social life. The instructor in the field of rural sociology finds his work less difficult than it has been but he still carries the handicap of teaching a body of knowledge for the most part still in the process of being 
made. The contrast between the teaching problem in the rural field and the urban is vividly felt by every instructor who has classes in both subjects.

It would be too much to claim a distinct teaching technique for the rural sociologist. It is, however, safe to maintain that rural sociology has its own program and that, as a part of the college curriculum, there is need of formulating this program in a catholic manner that each element may receive reasonable emphasis.

At the present time there is one difficulty that every teacher of rural sociology experiences. Cities the nation over are essentially alike. The differences between urban conditions are not such as to create a difficulty in the teaching of urban sociology. In rural sociology, however, the situation is such that geographical and local variations must ever be kept in mind. If the student is to feel personal contact with the subject, due regard must be paid to the conditions as he knows them in his own community. Opportunity has to be provided for him to grasp the significance of such facts as he has or can discover in the life of a rural people that he personally knows. At the same time he must be kept from seeing all rural life through his own contacts. And because of the variations in rural life conditions, considered nation-wide, this is in its teaching aspects a more difficult problem than any that arises in the teaching of urban sociology.

The teacher of rural sociology also wrestles with another difficulty that he escapes in the urban science. That is the task of isolating country from village society. The latter has not yet a sociology of its own, and yet in teaching rural sociology it is constantly necessary to contrast village life and that of the open and remote country. Of course, the two societies are bound together by intimate and common interests. This statement of intimacy and mutual relationship is true also of rural and urban societies. The latter groups, however, can be separated for the purposes of teaching without difficulty; at present the former must be treated together since the village is so largely the natural center for the group interests of the rural people. The teacher cannot do justly by the student unless he leaves him realizing both the natural variations in rural life conditions and the necessary 
distinction in science between country and village social life. If the material the teacher uses, texts and articles, more carefully observed these distinctions his task would not be nearly so difficult. One of the interesting outcomes of this situation that promises relief to the teacher of rural sociology is the increasing attention that village social life is receiving. Alongside rural sociology there is rapidly developing a village sociology which will soon be a science by itself.

The development of rural sociology has been accelerated by the pressure of social need. It has formed itself in the atmosphere of applied science. Experience has demonstrated that country welfare cannot be maintained merely by making farming more profitable. Country-life leadership has been forced to recognize the social problems, for the farmers themselves have repudiated a program exclusively economic. The demand for assistance from the colleges in solving the social problems of rural and village groups has been incessant and urgent. Students looking forward to residence or to social work in the country have elected rural sociology courses expecting the practical purposes of the courses to be given emphasis. This expectation has added to the courses' zest, but it has also at times removed the students from the atmosphere of scientific investigation into that of mere applied knowledge. The influence of the extension service of the agricultural colleges has added to the pressure upon the sociologist for propagable information, when, first of all, there has been need of gathering a substantial body of fact. As one would expect there has resulted a medley of counsel in regard to social uplift in country districts that has irritated some of the rural people and confused the social workers. This situation has disclosed itself in nearly every conference of national character where rural social problems have been given a place upon the program. The era of cocksureness with reference to the social panaceas to be gulped down by rural folk has about passed, and everywhere there is a disposition patiently to collect the facts regarding rural society and build up a science of understanding, even if meanwhile counsel regarding country life needs be given with less confidence and in less profusion. And this is the pathway of progress for the science. Nothing has more 
certainly exposed the elementary attainments of rural sociology in the past than the dogmatic stressing by some would-be reformers of the "one thing needed" to cause rural society to flower in perfection. The student of urban social life has seldom been tempted to assume such an attitude because he has been forced to realize the complexities of the social demands of the cities. People who live in the country are no less human than their city brethren and they do not present in their grouping a single problem to be solved, but rather a complex social demand which requires reasonable satisfactions. No scientist would advocate solving the urban problem, for to estimate the needs of city social life as one problem would seem foolish. It has been the pressure for information regarding social needs on the part of propagandists and social workers for application in the rural field that has betrayed the student of rural society as a scientist and made him at times an overconfident advocate.

Farmers as a class are irritated by reformers who come forward with a "cure-all" for country-life difficulties. The vocation of soil cultivation teaches caution with respect to such simple diagnosis. The farmer learns from painful experiences that there are many factors that condition success in food production and he looks askance, even with deep hostility, upon anyone who appears with one solution for all the difficulties in any department of rural concern. His quickness to react against such preachment has occasionally led him to mistake emphasis and concentration upon one particular element of rural need as an assumption that were the one problem solved all would be well. In such cases the ruralwelfare worker has had his message hindered by a greater obstacle than the conventional inertia to which the hostility has been charged. Urban folk may more easily be led into the fallacy of simplicity when diagnosing difficulties, economic or social, because they have isolated experiences that prevent their understanding the normal working of the causal laws of production. This fundamental difference between the thinking of people in the country and those in the cities has, in the past, been passed over lightly, and the farmer's mistrust of a one-idea program has been misinterpreted as mere conservatism. Poultry are more simple than 
people and yet the farmer has listened patiently to social enthusiasts who have pictured all rural life made perfect by the consolidated school, or the union church, or the co-operative society when he would leave in disgust were a poultryman to declare that a single procedure would guarantee one's success in raising leghorn hens.

In fairness to the problem of the teacher of rural sociology it must be granted that the farmer has not assisted in the accumulation of social information as might have been expected. There are differences east and west, but generally the farmer is sensitive to any investigation of his social conditions. He seems to assume that he is on the defensive and is often quick to take offense when for his own interests he should be eager to co-operate. This by no means indicates that the average farmer is well satisfied with the social conditions of his environment, for he has no hesitation in telling you his complaints. When he is called upon, however, to assist in a cold, scientific investigation of the situation against which he complains, he frequently stands aloof or even bitterly protests. This attitude is rapidly passing, and perhaps the farmer's distrust has been of the scientist rather than of his science. In order to reduce this suspicion to its minimum, emphasis has been placed upon the need of the rural sociologist's having been himself in his boyhood a worker on the farm. It so happens that the understanding of people does not necessarily come from having shared their experiences, and too much confidence has been placed upon the value of personal, individual country-life experiences as a foundation for the rural sociologist in his intimate relations with farmers. Vocational experiences in early life may, as the newer psychology shows in detail, easily become a separating obstacle rather than a basis for friendly appreciation when the adult comes into association with a group of which he was once a member. The point of emphasis has been wrong. It is important not that the rural sociologist was once a farmer; it is imperative that he know without prejudice farmers as they are now in the section where he has contact with them.

The rural sociologist at the present time has need to keep in mind all the conditions that influence his teaching problem when he constructs his college program. In his classes he may expect men 
and women who bring to the institution the impress of the social life of representative farming communities. Among his students also will be many who will return to rural communities and to a greater or less degree become leaders in their chosen localities. That the institution may contribute its just share to country-life progress the courses must also have definite motives. One such teaching purpose is the establishment of sound social standards for rural groups. No product of the classroom is likely to have a more lasting value than this. If the student by reports and discussions can be led to measure the failures and successes of his community in comparison with conditions reported by his class associates in other localities a wholesome basis is laid for future activities in community service. Under such circumstances it is difficult for a student to leave the course with the dangerous confidence that he fully understands the needs of a community and has nothing more to know. It is, of course, impossible for him ever to regard his community, after having made many comparisons between the social life as it is and as it might be, as a finished product. In this way the instruction removes both the contentment of conservatism and the simplicity of the would-be reformer.

By having reports made from time to time by the student regarding the social conditions of his own community with respect to the problem before the class for discussion there naturally develops a clear and vivid conception of the situation in various localities. This series of reports forces each student to become conscious of the failures of his own community as compared with the higher standards of others and he gradually tends to construct an extensive social program for the group life he knows best.

Another purpose of the courses in rural sociology is the furnishing of accurate information regarding social conditions and resources in the country. Future rural leadership must be given a clear understanding of the country-life situation in its many aspects. Here it is especially necessary that the student learn how to collect social facts, how to estimate the value and determine the significance of surveys, public reports, and other material from which the sociologist draws his conclusions. In the former pioneering days it has been difficult to give the student at this point the adequate assistance that he has had a right to expect. The instructor has 
felt obliged either to depend upon lectures or upon a text to a degree that has diminished the student's opportunity for first-hand knowledge of the raw material of the science. The source books containing valuable collections of readings that are being prepared and are likely to be published soon will certainly be helpful, especially in institutions where the library material is inadequate. However, these collections, valuable as they will be, must not satisfy the instructor in his desire to bring the student into contact with original material. It will often prove profitable to require of the students a bibliography representing the collection that he himself regards as best for the purpose of outside reading. The instructor can, near the end of the courses, criticize these various collections and thus help the student in his effort to determine the value of articles and reports on rural conditions.

No course in rural sociology fulfils its purpose unless it has a part in increasing popular interest in the social problems of the country. It especially has an obligation with reference to the future leadership of the country communities. This seems so essential a part of the teaching program as to need little comment. In practice, however, the teacher in the state college sometimes finds himself limited by the lack of interest that his colleagues in agriculture take in the social side of country affairs. Courses in rural sociology have been added to the curriculum of agricultural colleges recently and they find the older vocational subjects in possession of the field. Unless checked by administrative policy, some departments encourage the student to attempt premature specialization and everything is done to discount the need of the student's having an adequate preparation for rural leadership as well as the basis for business success. The vitality of the courses in rural social matters best meets this situation which fortunately is rapidly passing.

Rural sociology is merely a division in a larger field and it has a purpose in giving the student of general sociology the rural viewpoint. It is certainly unfortunate if the courses of the department are elected only by those who look forward to living in the country. The attempt made at some of the agricultural colleges to deny the students any courses in urban sociology is the result of regarding the rural and urban environments as not having relationship. As a matter of fact, both rural and urban social conditions 
need to be understood by anyone who wishes to have knowledge of either environment, and for this reason in our rural courses we need to keep in mind the interests of those who wish to see the social field as a whole. To construct the courses in a narrow spirit of regard only for the country-life student is to delay the progress of the science and to remove it from the current of inspiration. Courses of rural sociology should not be given for the purpose of furnishing rural self-satisfaction for the men and women who are destined "to return to the land" after having received from the college a prophylactic against the dangers of urban attraction. For the teacher the presence in the class of students whose major interests are outside the rural field proves a decided advantage, since, to win these students, the courses have to be taught in a catholic manner.

In developing his college courses the rural sociologist surely should not neglect their possible influence in attracting the more promising students into graduate study within the field of rural social science. The present difficulty that colleges experience in getting instructors qualified to teach rural sociology demonstrates that there is need of encouraging students who desire to teach college sociology to specialize along rural lines. The immediate future of the science will be largely decided by the character of the students that may at present become interested in rural sociology. No teaching method can do so much to win the attention of the best students to the significance of the rural field as the requirement of investigations from members of the class. In addition to the thesis, which may be presented at the end of the course and the reports frequently made concerning the social life of the student's own community, the use of topic questions for class discussions seems, in the experience of some teachers, more appealing to the majority of the students and more profitable than lectures and assigned readings. The larger the contribution of the student, the more acquainted he becomes with the raw material of the science, the more likely he is to realize the opportunity of graduate study. If the progress of rural social science is to prosper as it should, the college teacher constantly must send forward promising candidates for advanced study. 